\title{
A herpes-like virus disease in the blue king crab Paralithodes platypus
}

\author{
Albert K. Sparks \& J. Frank Morado \\ Resource Assessment and Conservation Engineering Division, Northwest and Alaska Fisheries Center, National Marine \\ Fisheries Service, National Oceanic and Atmospheric Administration, 7600 Sand Point Way N. E., Seattle, \\ Washington 98115, USA
}

\begin{abstract}
A virus was suspected, at the light microscopy level, to have infected bladder and antennal gland labyrinthal epithelium of the blue king crab Paralithodes platypus, causing severe damage. The lesions were characterized by marked nuclear hypertrophy and chromatin margination and the presence of a variably eosinophilic, amorphous ground substance. Within this ground substance, pleomorphic, more densely stained eosinophilic inclusions could be seen. Transmission electron microscopy confirmed the relation between the ground substance and nuclear inclusions, and revealed the presence of viral particles within the ground substance. Based on the nucleocapsid's site of development, morphological characteristics and size, the virus is believed to be a member of the family Herpesviridae.
\end{abstract}

\section{INTRODUCTION}

The Alaskan red (Paralithodes camtschatica) and blue ( $P$. platypus) king crab populations of the Bering Sea have experienced catastrophic declines since the late 1970's (Otto, R. S., Stevens, B. G., McIntosh, R. A., Wilson, S. J. unpubl.). By 1983, Bristol Bay (Fig. 1) legal male $(>134 \mathrm{~mm}$ ) and mature female (>89 mm) red king crabs were reduced to $6.0 \%$ (4.0\% and $6.5 \%$ respectively) of the estimated combined high of 187.7 million crabs in 1977. In the Pribilof District (Pribilof Islands) (Fig. 1), legal blue king crabs males (>134 mm) were reduced in 1984 to $6.4 \%$ of the 1977 estimated high of 9.4 million while sexually mature females were reduced to $8.7 \%$ of the estimated 1978 high of 35.5 million. During the same year, Northern District (St. Matthew Island) (Fig. 1) legal blue king crab males (>119 $\mathrm{mm}$ ) and mature females (>79 $\mathrm{mm}$ ) were reduced to $23.5 \%$ and $22.7 \%$ of the estimated highs in 1982 and 1980 of 6.8 and 2.2 million. Prerecruit red and blue king crab males were similary affected throughout the management districts.

As a result of these declines, an investigation into the possible role of disease was initiated in 1982. Light microscopical examination of stained sections revealed evidence of a viral infection of the bladder and antennal gland of both red and blue king crabs, as well as the golden king crab Lithodes aequispina, which has recently entered the commercial fishery.
Transmission electron microscopy of fixed tissues from an infected blue king crab Paralithodes platypus revealed a herpes-like virus. In this paper we report our initial observations.

\section{MATERIALS AND METHODS}

Blue king crabs were collected in the winter $(n=21)$ and summer $(n=39)$ of 1983 near the Pribilof Islands and in the spring $(n=6)$ and summer $(n=2)$ of 1983 and the summer $(n=68)$ of 1984 from the vicinity of St. Matthew Island in the western Bering Sea. Crabs were necropsied aboard ship where small portions of the major organ systems were excised and fixed in Helly's or Bouin's fixative for light microscopy (LM). When tissues were collected for transmission electron microscopy (TEM), the samples were fixed in a solution of $0.75 \%$ glutaraldehyde, $3 \%$ formalin, and $0.5 \%$ acrolein in $0.1 \mathrm{M}$ sodium cacodylate buffer, $\mathrm{pH} 7.4$, with $5.5 \%$ sucrose and $0.02 \% \mathrm{CaCl}_{2} \cdot \mathrm{H}_{2} \mathrm{O}$. The samples were rinsed and stored in appropriate solutions (LM: $50 \%$ and $70 \%$ ethanol, TEM: buffer) and transported to our laboratory for processing and microscopical examination. The methods of processing for routine $\mathrm{H} \& \mathrm{E}$ preparations and transmission electron microscopy have been described earlier (Sparks et al. 1985). Additional stains applied to sectioned material were Feulgen picromethyl blue and Feulgen's nuclear stain. 


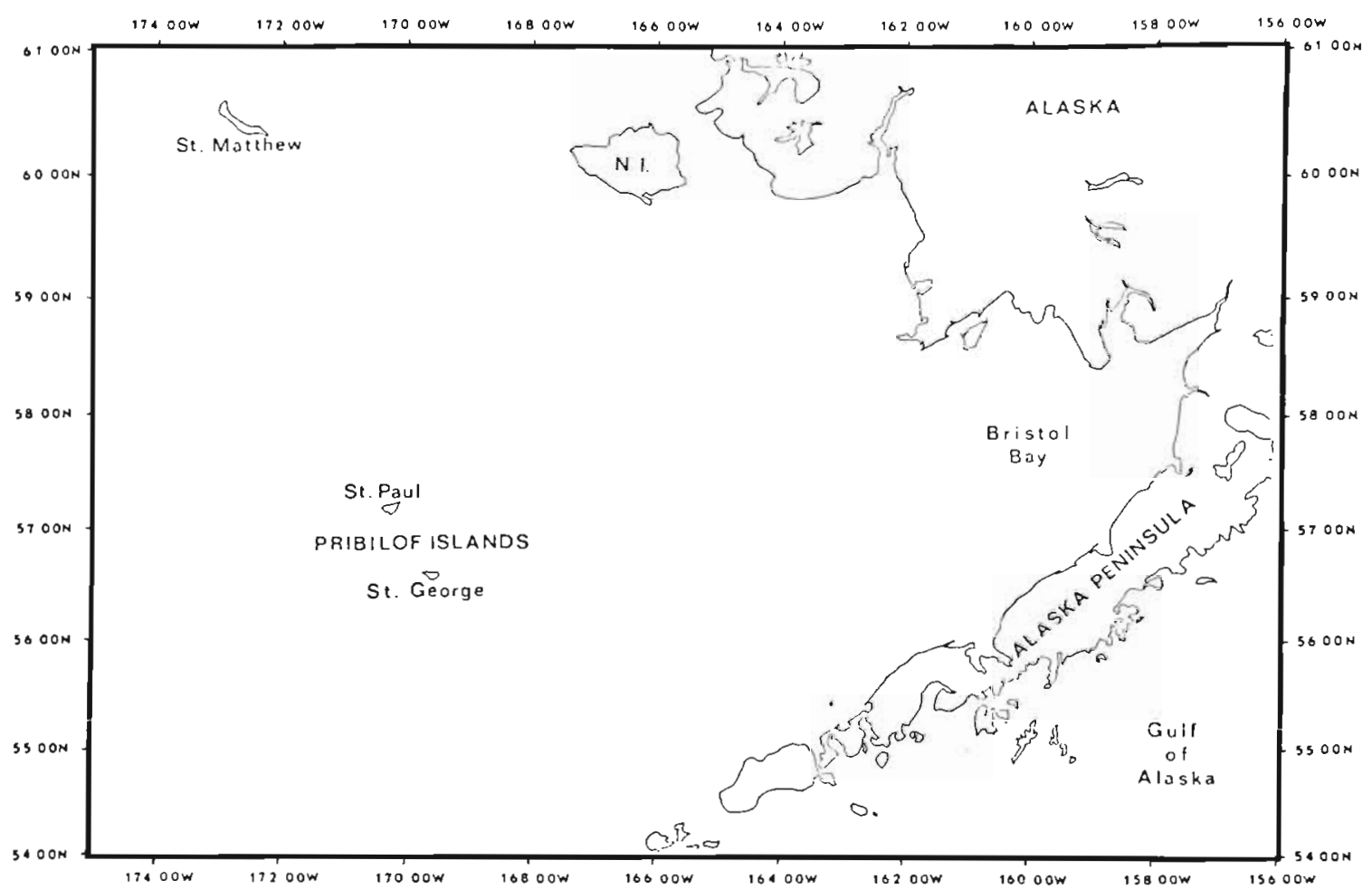

Fig. 1. Diagram of eastern Bering Sea showing general collection sites. NI = Nunivak Island

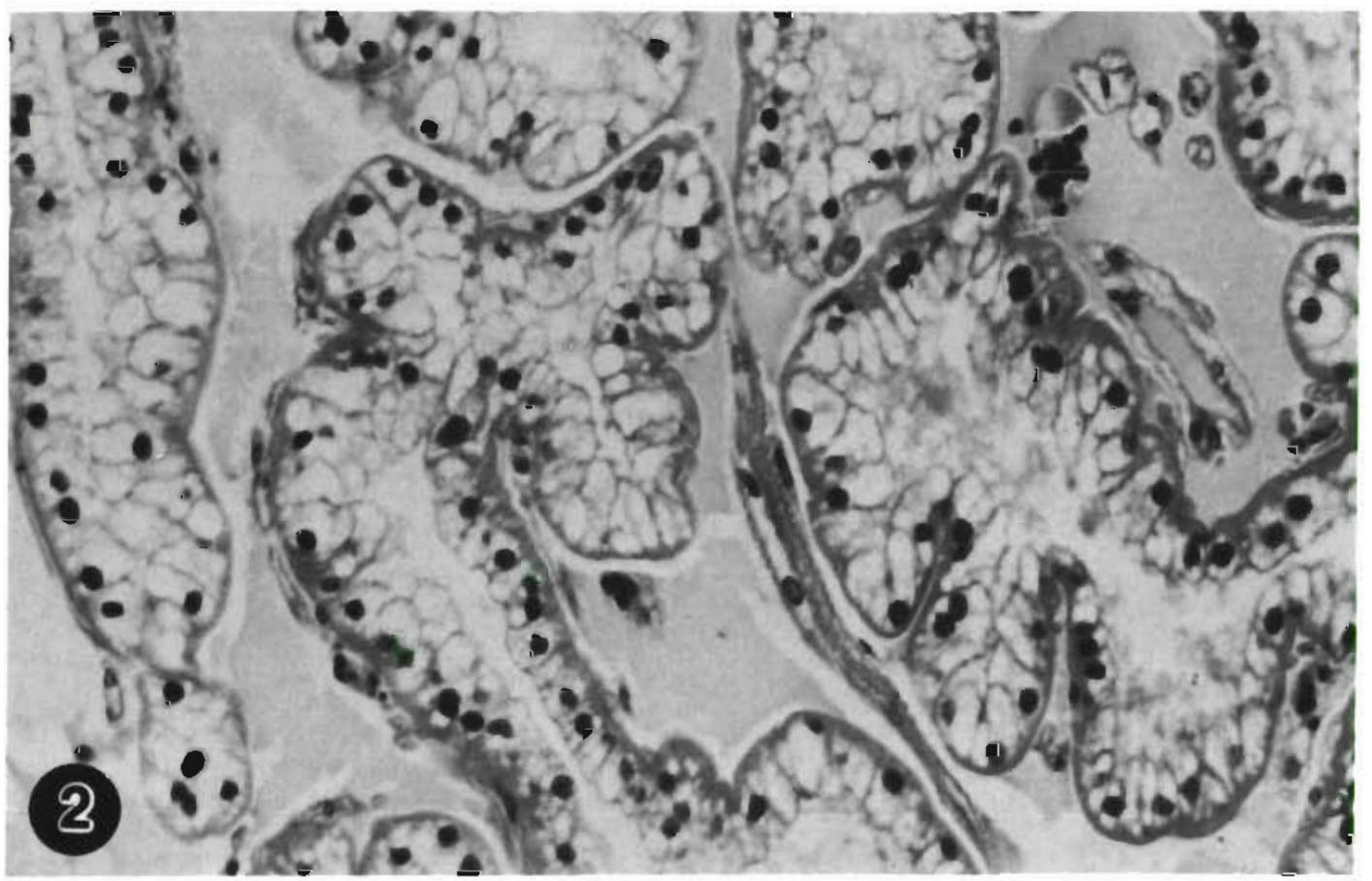

Fig. 2. Paralithodes platypus. Nomal bladder. H \& E. $260 \times$

\section{RESULTS}

Nuclei of the bladder and labyrinthal epithelium of blue king crabs with the putative viral infection were markedly hypertrophied, had marginated chromatin, and possessed a variably stained eosinophilic ground substance with or without eosinophilic inclusion bodies (compare Fig. 2 and 3, and Fig. 4 and 5). The 


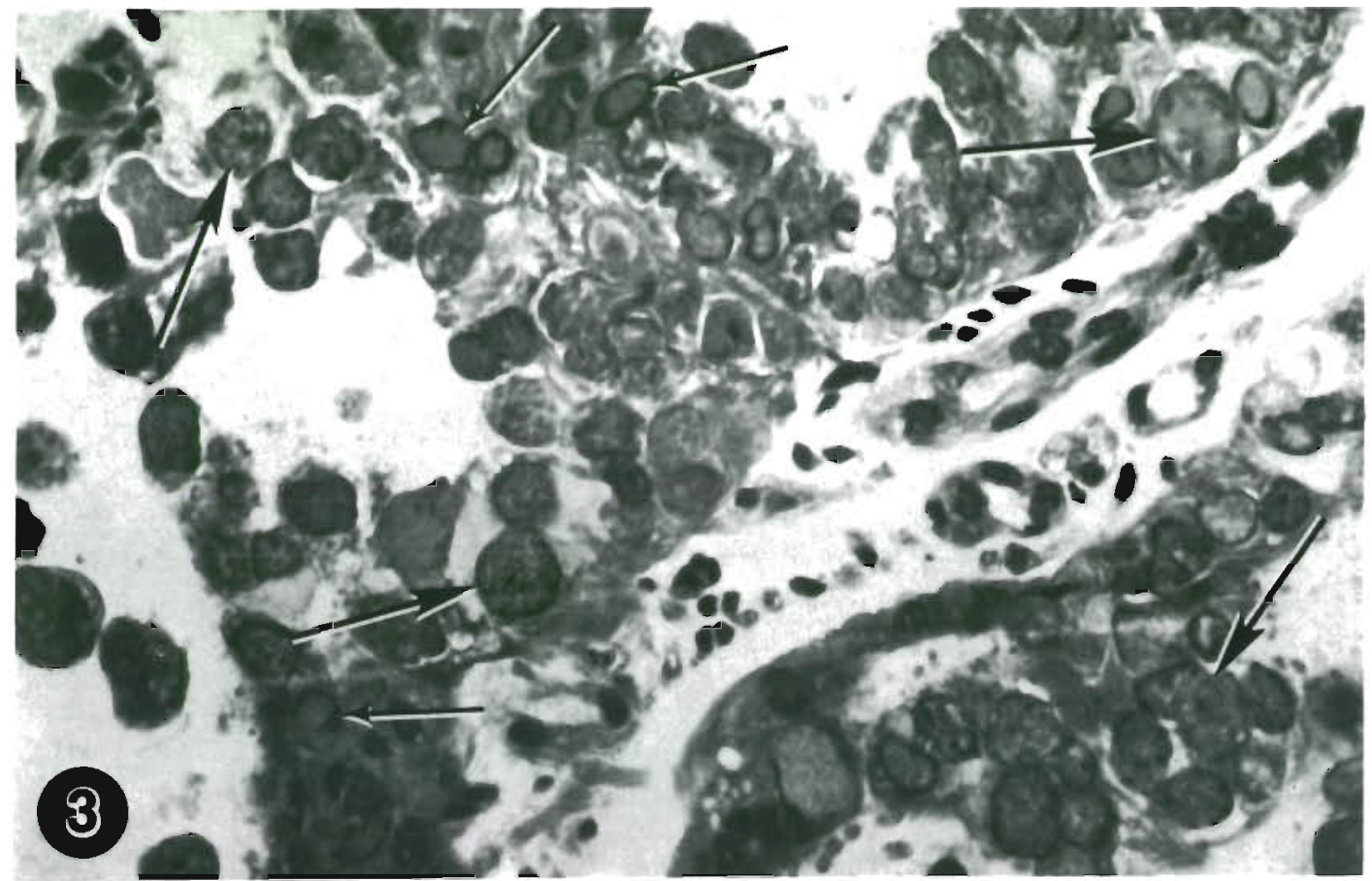

Fig. 3. Paralithodes platypus. Heavily infected bladder. Most of the nuclei are greatly hypertrophied and have marginated chromatin. The more greatly hypertrophied nuclei contain ground substance and inclusion bodies (large arrows). Other nuclei are less hypertrophied and possess marginated chromatin due to the presence of ground substance (small arrows). $\mathrm{H} \& \mathrm{E}$. $260 \mathrm{X}$

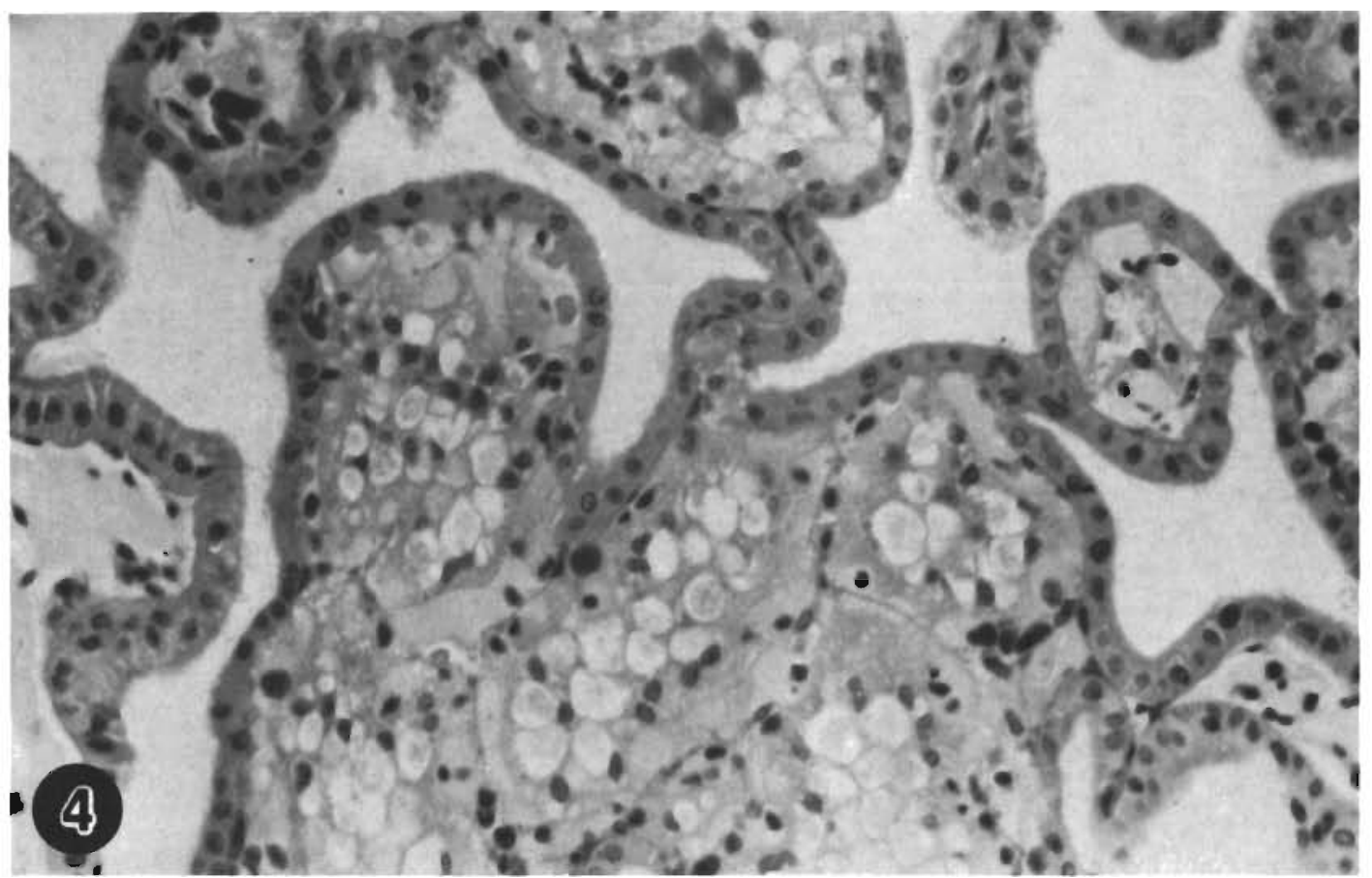

Fig. 4. Paralithodes platypus. Normal antennal gland. H \& E. $260 \times$

ground substance was generally spherical in shape, and was responsible for the varying degrees of nuclear hypertrophy and chromatin margination of infected cells (Fig. 3, 5, 7). The eosinophilic nuclear inclusions were pleomorphic and were observed only within and in association with the ground substance of markedly hypertrophied nuclei (Fig. 3, 5, 6). In contrast, the ground substance was commonly seen alone within the 


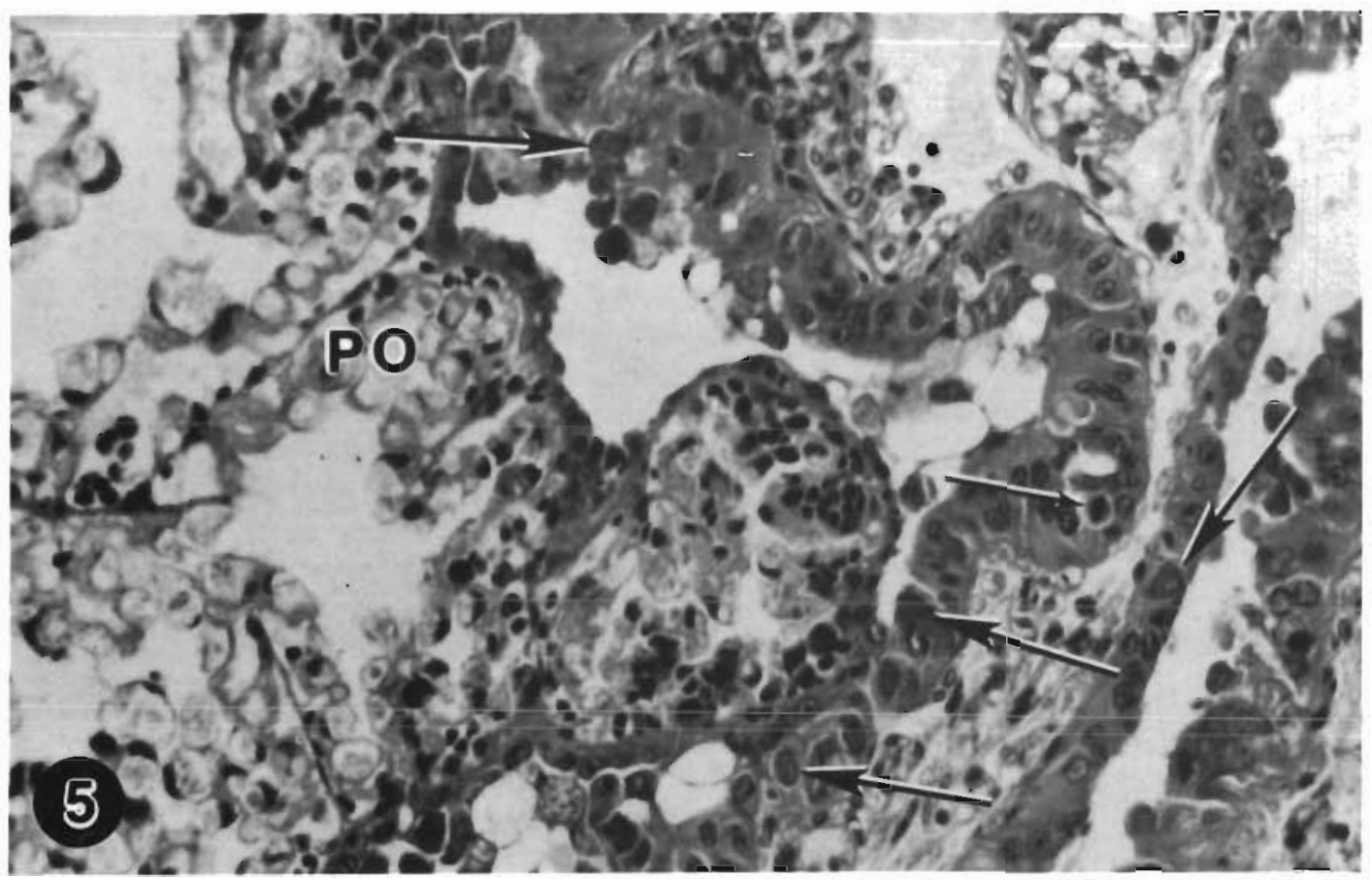

Fig. 5. Paralithodes platypus. Moderately infected labyrinthal epithelium of antennal gland. Several nuclei are slightly hypertrophied and with chromatin margination due to ground substance (large arrows), but many more are normal. Note the mitotic figure (small arrow). The podocytes (PO) are normal. H \& E. $260 \times$

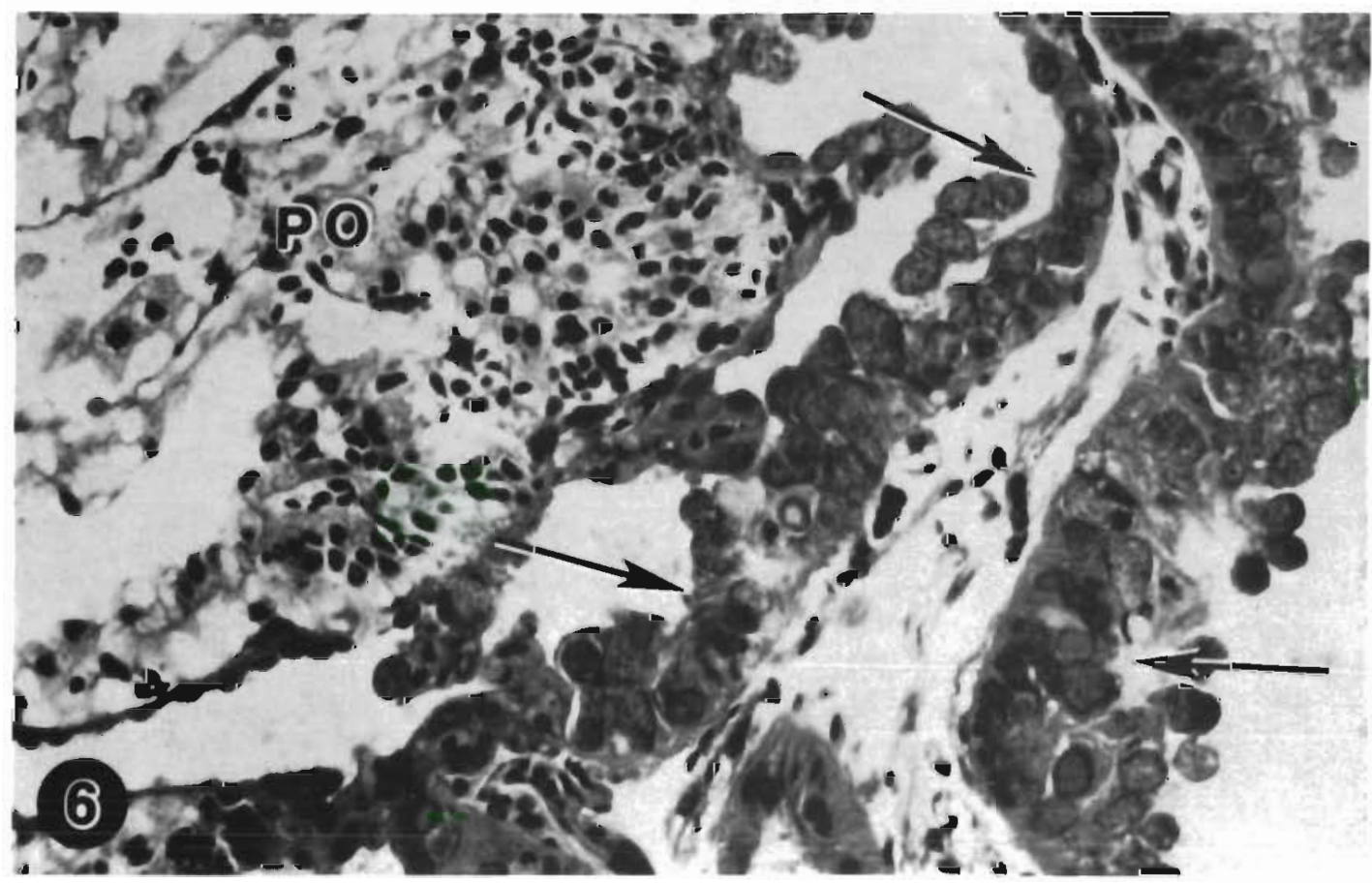

Fig. 6. Paralithodes platypus. Heavily infected labyrinthal epithelium of antennal gland (arrows). Most if not all of the nuclei are hypertrophied, have chromatin margination and possess both ground substance and inclusion bodies. The podocytes (PO) are degenerating but are not infected. H \& E. $260 x$ 


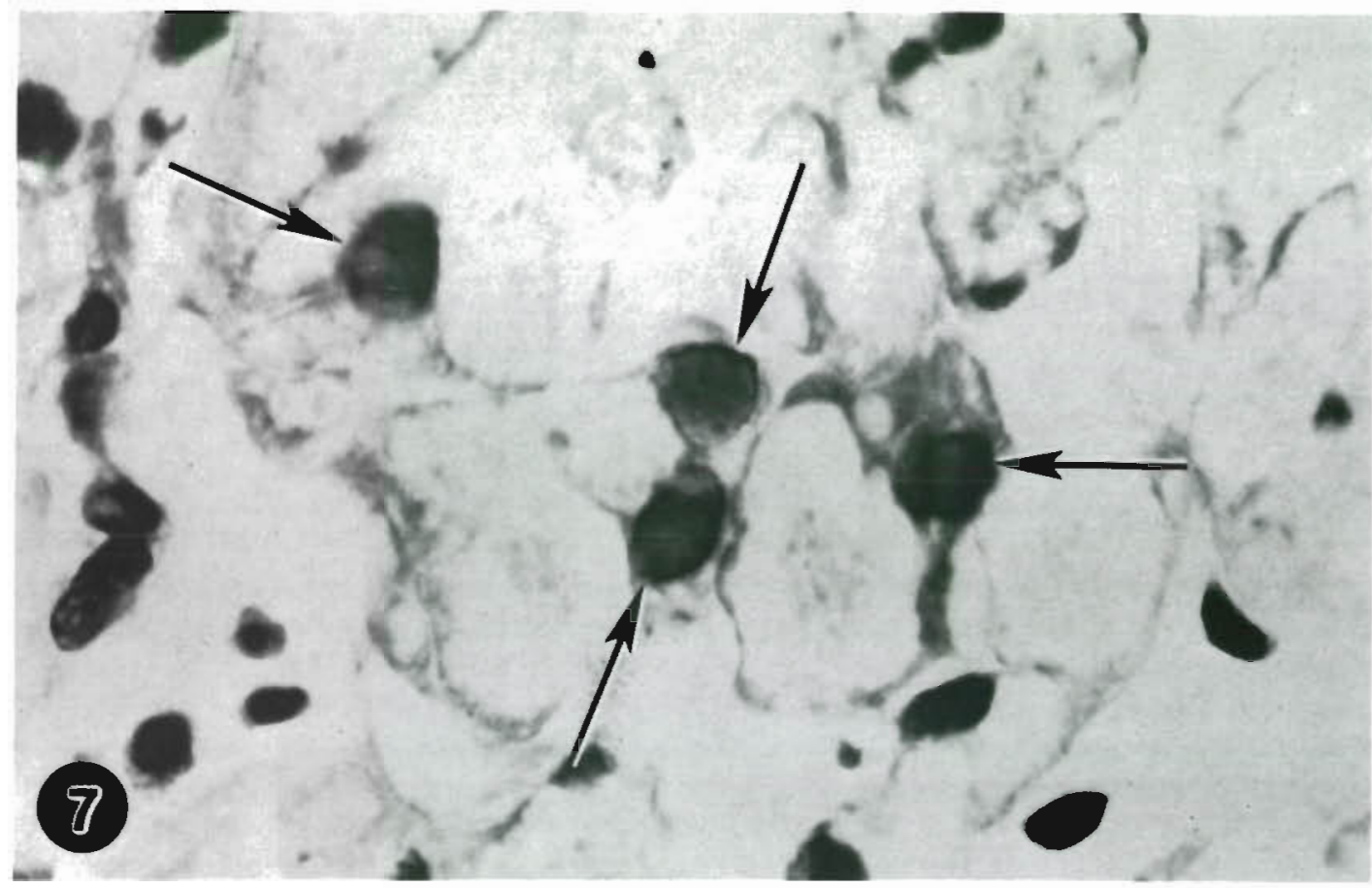

Fig. 7. Paralithodes platypus. Four hypertrophied nuclei of podocytes (arrows). All have chromatin margination due to the presence of the ground substance. H\&E. $1100 \times$

nucleus of infected cells, regardless of the degree of nuclear hypertrophy and chromatin margination.

In heavy infections (Fig. 3), the normal architecture of the bladder (Fig. 2) was virtually destroyed. Presumably, the hypertrophy of the nuclei eventually ruptured the cell membranes, freeing the persistent nuclei into the lumen. Despite the resulting epithelial damage, an inflammatory response was weak or lacking completely.

The antennal gland was similarly affected (compare Fig. 4 to Fig. $5 \&$ 6). In moderate infections (Fig. 5) many nuclei of the labyrinthal epithelium appeared normal, but multiple foci contained nuclei in various stages of hypertrophy and chromatin margination (ground substance displacement of nucleoplasm). In more severe infections, the labyrinthal epithelium became indistinguishable from heavily infected bladder, remaining recognizable only by its association with remnants of podocytes in the coelomosac (Fig. 6). Podocytes also were infrequently infected (Fig. 7), exhibiting similar nuclear hypertrophy and chromatin margination. Inclusion bodies were not observed within the nuclei of podocytes.

Transmission electron microscopy confirmed the nuclear hypertrophy, chromatin margination, and the relation of the ground substance with the eosinophilic inclusion bodies (Fig. 8) observed at the light microscopy level. Higher magnification (Fig. $9 \& 10$ ) revealed the presence of numerous hexagonal virus particles in the nuclei of infected cells. These virus particles were similar in size and morphology to members of the Herpesviridae. The hexagonal nucleocapsid consisted of a nucleoid containing an electron-dense cylinder, 55 to $60 \mathrm{~nm} \times 90$ to $105 \mathrm{~nm}$, surrounded by a toroidal structure, 90 to $105 \mathrm{~nm}$, of medium electrondensity, and an encompassing capsid composed of 2 distinct electron-dense layers, resulting in an unenveloped nucleocapsid approximately 140 to $165 \mathrm{~nm}$.

Both the ground substance and inclusion bodies were Feulgen-negative or weakly Feulgen-positive. Transmission electron microscopy demonstrated that the ground substance was composed of finely granular material in which viral particle formation took place. The nucleoplasm was correspondingly reduced as the ground substance increased in size. The inclusion bodies were pleomorphic but their terminal ends appeared uniform when only a few virus particles were present. When nucleocapsids were more numerous, the ends of these inclusion bodies appeared frayed. Virus particles at various stages of development were commonly observed within the ground substance or virogenic stroma. Few particles were seen in the nuclear inclusions.

Because of the characteristic pathogenesis, viral infections were diagnosed by light microscopy in 7 of 21 , and 2 of 39 crabs collected from Kodiak Island, Gulf of Alaska area in early 1983 and summer 1983, respectively. Eight crabs collected near St. Matthew Island in 


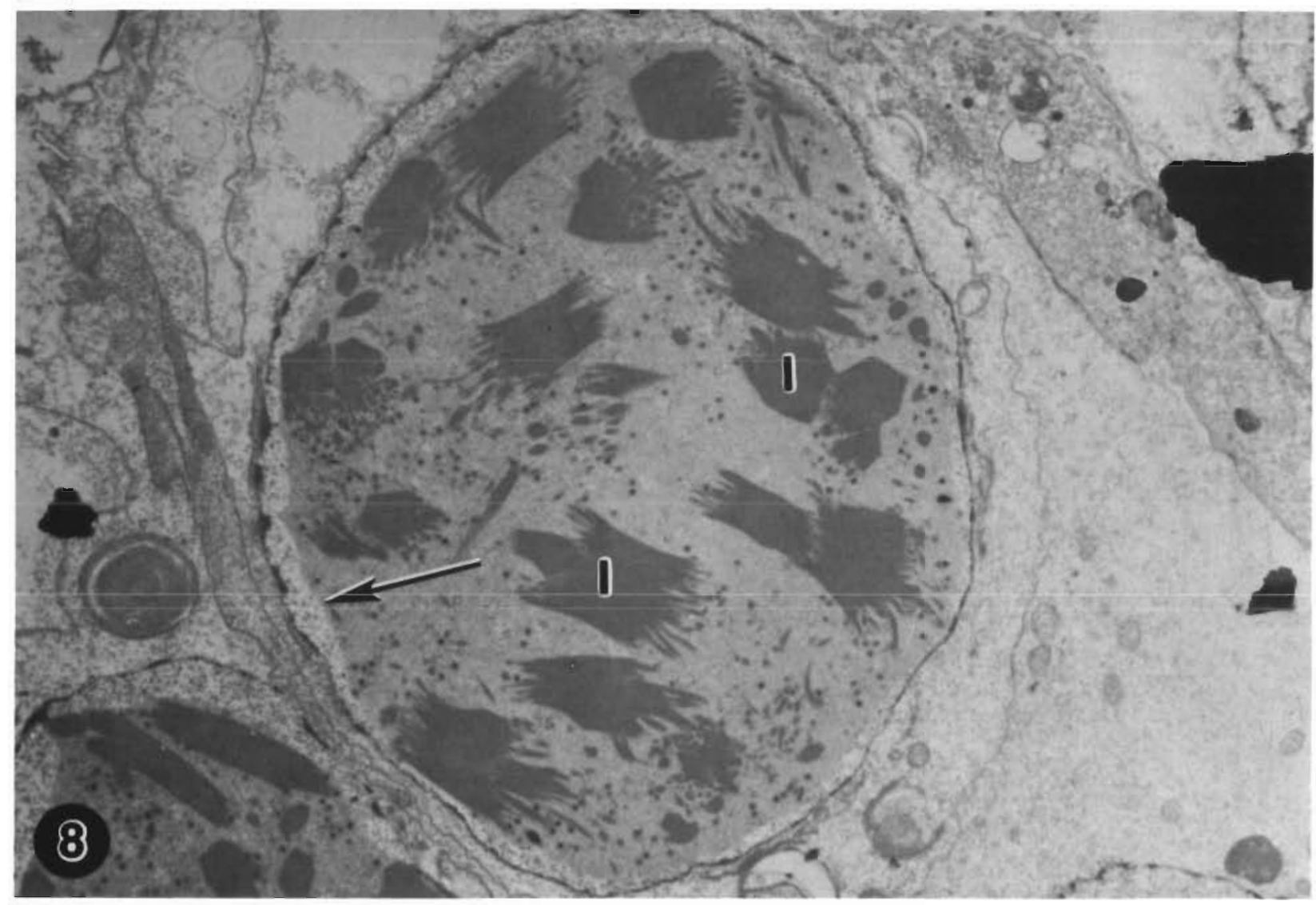

Fig. 8. Paralithodes platypus. TEM micrograph of infected nucleus. Several small virus particles can be seen in the virogenic stroma between the inclusion bodies (I). Note margination of chromatin (arrow) and the frayed ends of the inclusion bodies which are in the virogenic stroma. $14000 x$

1983 were apparently free of infection, but 8 of 68 necropsied in the summer of 1984 had patent infections.

\section{DISCUSSION}

Herpes-like viruses have been previously reported in hemocytes of the American oyster Crassostrea virginica (Farley et al. 1972, Farley 1978) and within hemocytes of the blue crab Callinectes sapidus (Johnson 1976), both from the Atlantic coast of North America. Another herpes-like virus was found in mesodermal cells of male gonad of the mud crab $R h_{i-}$ thropanopeus harrisii from France (Payen \& Bonami 1979). In the crab-like anomuran Paralithodes platypus we found cells of the bladder epithelium and labyrinthal epithelium of the antennal gland were the primary sites of infection. Podocytes were also infected but to a lesser degree.

The virus described here appears to be morphologically similar to the herpes-like virus of Callinectes sapidus except that the nucleoid and its components are slightly smaller. We consider the 2 electron-dense layers that encompass the nucleoid (cylinder and toroid) as part of the capsid, despite the apparent space between them, thus the virus is naked or unenveloped within the nucleus. This is consistent with current descriptions of the Herpesviridae of vertebrates (Roizman 1982, Matthews 1982) and with the herpes-like virus of the mud crab (Payen \& Bonami 1979). It seems unlikely that an envelope in the traditional sense would be present around nucleocapsids within the nucleus since the membrane-synthesizing mechanisms are located in the cytoplasm and not within the nucleus (Alberts et al. 1983). In addition, the hexagonal appearance of the 2 layers is typical of capsids of herpesviruses. Nii et al. (1968) and Tseng (1980) have shown developing capsids and mature nucleocapsids of Herpes simplex virus with 2 electron dense layers. The relatively wide space between the 2 capsid layers may be a characteristic of the blue king crab virus or an artifact of preparation. The blue crab virus (Johnson 1976) is slightly larger than the virus described here. Both viruses are considerably larger than those found in the mud crab and the oyster.

It is likely that the ground substance is a virogenic 

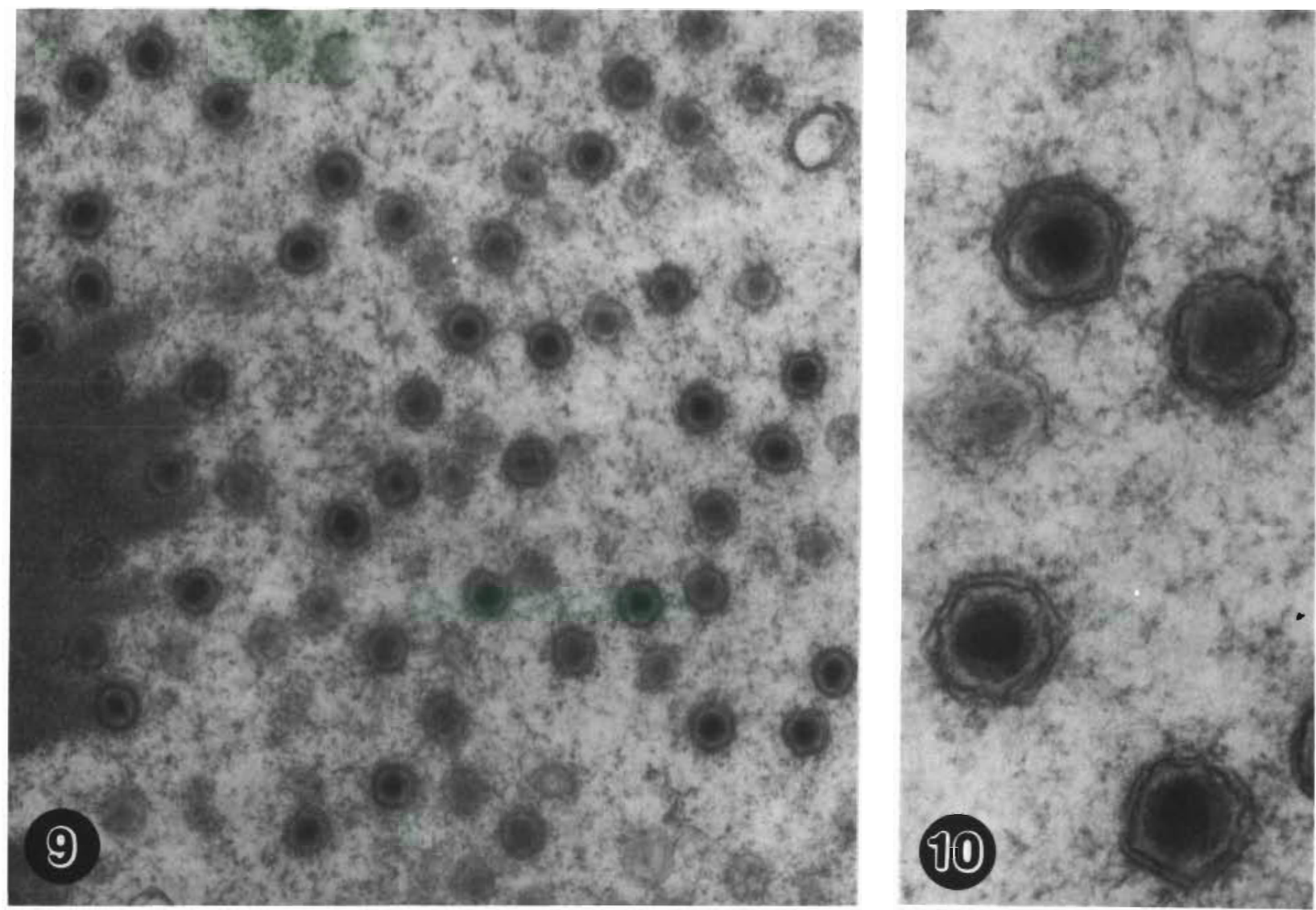

Fig. $9 \& 10$. Paralithodes platypus. At higher magnification, the nucleocapsid's morphology is evident. The nucleocapsid consists of a nucleoid containing an electron-dense cylinder and toroid of medium-density and a double layered hexagonal capsid. $29000 \times$ and $106000 \times$, respectively

stroma consistent with the description of Cowdry typeA inclusions (Cowdry 1934) and the 'superficial' intranuclear inclusion body of Shipkey et al. (1967). In addition, the eosinophilic inclusion bodies of the herpes-like virus in the blue king crab are similar to the description of Cowdry type-B inclusions (Cowdry 1934). However, the origin and function of the inclusion bodies in the blue king crab are unclear. Nor is it clear why these inclusions apparently become more disorganized or eroded at the ends with increased viral particle production, since the nucleocapsids are not embedded in these inclusions. Wolf \& Darlington (1971) described a similar type of irregular inclusion in cultured cells infected with the channel catfish virus, also a herpesvirus. They believed the inclusions were a result of viral infection.

Although it seems unlikely that blue king crabs with infections progressing to virtual total destruction of the bladder and antennal gland can survive and repair the massive tissue damage, we do not have unequivocable evidence that the disease is fatal. The herpes-like virus of Callinectes sapidus is often fatal, but the percentage of infections causing death is not known. Death from a naturally acquired infection may take $60 \mathrm{~d}$ (Johnson 1983), but experimental infections transmitted by feeding of infected tissues or by injection of infected hemolymph cause death in 30 to $40 \mathrm{~d}$ (Johnson 1978). The virus in the mud crab (Payen \& Bonami 1979) is not known to cause mortalities. In the American oyster mortalities appear to be stress related (Farley et al. 1972). Both the percentage of infected crabs that die of the disease and the interval from initial infection to fatal termination must be determined before the impact of the disease on blue king crab populations can be established.

Acknowledgements. We thank Dr. Phyllis T. Johnson for initial confirmation and subsequent discussion concerning the present work. However, we would like to point out that Dr. Johnson is not in agreement with our morphological description of the virus particle within the nucleus of an infected cell. We would also like to thank Drs. Donald V. Lightner, Theodore R. Meyers and James R. Winton for their critical reviews of the manuscript and helpful suggestions. We greatly appreciate the time and effort by several members of the Kodiak Laboratory in Kodiak, AK (NMFS) and Alaska Department of Fish \& Game in Kodiak who were actively 
involved in the collection and necropsy of specimens. Finally, we would like to acknowledge Virginia $M$. Bryant and Theresa M. Armetta for their technical assistance, in addition to field collections and necropsies.

\section{LITERATURE CITED}

Alberts, B., Bray, D., Lewis, J., Raff, M., Roberts, K., Watson, J. D. (1983). Molecular biology of the cell. Garland Publ., Inc., New York \& London

Cowdry, E. V. (1934). General review: The problem of intranuclear inclusions in virus diseases. Arch. Pathol. 18: $527-542$

Farley, C. A. (1978). Viruses and virus-like lesions in marine mollusks. Mar. Fish. Rev. 40: 18-20 ,

Farley, C. A., Banfield, W. C., Kasnic, G.. Jr., Foster, W. S. (1972). Oyster herpes-type virus. Science (Wash., D. C.) 178: 759-760

Johnson, P. T. (1976). A herpeslike virus from the blue crab, Callinectes sapidus. J. Invertebr. Pathol. 27: 419-420

Johnson, P. T. (1978). Viral diseases of the blue crab, Callinectes sapidus. Mar. Fish. Rev, 40; 13-15

Johnson. P. T. (1983). Diseases caused by viruses, Rickettsiae, bacteria, and fungi. In: A. J. Provenzano, Jr. (ed.) The biology of Crustacea; Vol. 6, Pathobiology, Chap. 1 Academic Press, New York and London, p. 1-78

Matthews, R. E. F. (1982). Classification and nomenclature of viruses. Intervirology 17: 1-199

Nii, S., Morgan, C., Rose, H. M. (1968). Electron microscopy of Herpes simplex virus. II. Sequence in development. J. Virol. 2: 517-536

Payen. G. G., Bonami, J.-R. (1979). Mise en evidence de particules d'allure virale associees aux noyaux des cellules mesodermiques de la zone germinative testiculaire du crabe Rhithropanopeus harrisii (Gould) (Brachyoure, Xanthide). Rev. Trav. Inst. Pneches marit. 43: 361-365

Roizman, B. (1982). The Herpesvirus, Vol. 1. Plenum Press. New York and London

Shipkey, F. H., Erlandson, R. A., Bailey, R. B., Babcock, V. I., Southam, C. M. (1967). Virus biographies. II. Growth of Herpes simplex in tissue culture. Expt. mol. Pathol. 6: 39-67

Sparks, A. K., Morado, J. F., Hawkes, J. W. (1985). A systemic microbial disease in the Dungeness crab, Cancer magister, caused by a Chlamydia-like organism. J. Invertebr. Pathol. 45: 204-217

Tseng, C. H. (1980). Atlas of ultrastructure - Ultrastructural features of pathology. Appleton-Century Crofts, New York

Wolf, K., Darlington R. W. (1971). Channel catfish virus: a new herpesvirus of ictalurid fish. J. Virol. 8: 525-533

Responsible Subject Editor: Dr. G. Lauckner; accepted for printing on January 13, 1986 